\title{
The effect of light curing units and modes on cytotoxicity of resin-core systems
}

\author{
Gulfem Ergun ${ }^{1}$, Ferhan Egilmez ${ }^{1}$, Isil Cekic-Nagas ${ }^{2}$ \\ ${ }^{1}$ Department of Prosthodontics, Faculty of Dentistry, Gazi University, Ankara, Turkey \\ ${ }^{2}$ School of Dental Technology, Hacettepe University, Ankara, Turkey
}

Correspondence:

Süslü sokak 14/9

Tandogan/Ankara, Turkiye

ergungulfem@yahoo.com

Received: 28/09/2009

Accepted: $21 / 02 / 2010$

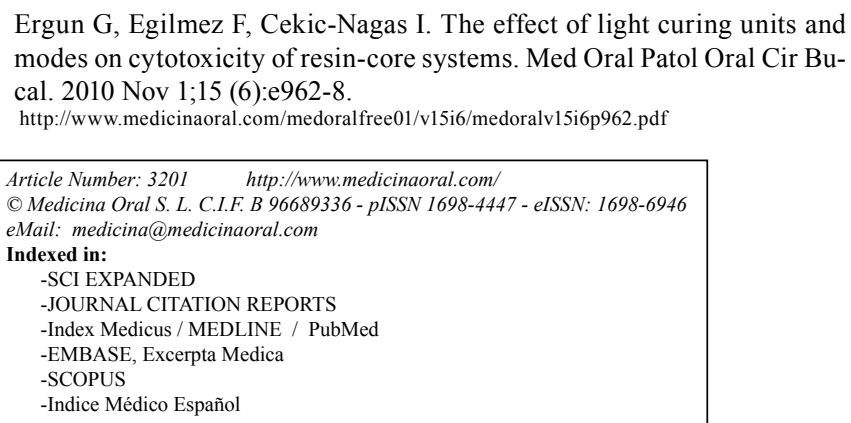

\begin{abstract}
Objective: The aim of this study was to compare the cytotoxic effects of various resin-based core materials that were cured with three light curing units (LCUs) in different modes on L-929 mouse fibroblast cells over $24 \mathrm{~h}$ and $72 \mathrm{~h}$ periods.

Study design: Eighty-four cylindrical discs ( $2 \mathrm{~mm}$ in thickness and $6 \mathrm{~mm}$ in diameter) of each material (Rebilda, Voco; Build-It FR, Pentron; Clearfil DC Core, Kuraray and Bis-core, Bisco) were cured by QTH LCU (soft-up and high-power modes), LED LCU (exponential and standard modes) and PAC LCU (normal and ramp-curing modes). Then the samples were aged for 24 and 72 hours in Dulbecco's Modified Eagle Medium/Ham's F12 (DMEM/F12). After each ageing interval, cytotoxicity of the extracts to cultured fibroblasts (L 929) was measured by MTT assay. The degree of cytotoxicity for each sample was determined according to the reference value represented by the cells with a pure culture medium. Statistical significance was determined by a multifactorial analysis of variance followed by one-way ANOVA and Tukey's post-hoc test or independent $t$ tests.

Results: Data showed that there are significant differences among resin based core materials, LCUs, curing modes and time factors $(\mathrm{p}<0.001)$. The test materials cured with the QTH and LED demonstrated statistically higher cell survival rates when compared with those cured with the PAC $(\mathrm{p}<0.001)$.

Conclusions: Differential toxic effects of the resin-based core materials cured with QTH, LED and PAC on the fibroblast cells may prove to be very important when suitable resin-core systems, LCUs and curing modes are used for operative restorations.
\end{abstract}

Key words: Resin-core materials, light curing units, curing modes, cytotoxicity. 


\section{Introduction}

Recently, tooth-colored composite resin core materials have been used as core build-up materials to restore vital teeth in restorative situations where the pulp is at higher risk or non-vital teeth especially with rapidly escalating demand for esthetic restorations in dentistry (1). In clinical situations, resin core restorations are preferred because they can prevent root fractures of non-vital teeth; require minimal intervention and cavity preparation (2). The rapid increase in esthetic dental restorative techniques has dramatically increased the use of light sources to photocure resin composites. At present, four different types of light curing sources are available: quartztungsten-halogen bulbs (QTH), plasma arc (PAC), light emitting diodes (LED) and argon-ion laser (3). LCUs that utilize very high intensity light are almost universally recommended. These recommendations are generally based on the shorter curing times required when using high intensity lights with physical and mechanical properties comparable to those of QTH lights (4). High intensity lights may provide higher values of the degree of conversion (DC) and better physical properties during the curing process of the resin composite. A lower degree of conversion could affect the longevity of the composite core restoration, because an incomplete conversion may result in unreacted monomers, which might dissolve in a wet environment. This fact could directly affect biocompatibility of the resin composite restorations (5).

Traditionally, QTH lights have been used in a continuous output mode while emitting a fairly high irradiance. Recently, new curing methods have been introduced (the soft start and exponential, pulse and ramp curing and, high and low intensity modes) (1). The soft start protocol has the option of operation with an initial period of low intensity illumination followed by high intensity illumination, which should control stress growth during resin composite cure (6).

In vitro and in vivo studies have clearly identified that some components of restorative resin composites are toxic $(5,7)$. The mechanisms of cytotoxicity are related firstly to the short-term release of free monomers occurring during the monomer-polymer conversion. Secondly, long-term release of leachable substances is generated by erosion and degradation over time. Furthermore, ion release and proliferation of bacteria located at the interface between the restorative material and dental tissues are also implicated in the tissue response (7).

Virtually no information exists about the biological risks of light cured resin core materials that are commonly used clinically. With that in mind, the aim of the present study was to evaluate the in vitro cytotoxicity of resin core materials cured with different LCUs and curing modes. Accordingly, the following null hypotheses were tested:
1. The cytotoxic effects of cell culture evaluated at different experimental times show dependence on the type of resin core materials cured with different curing modes of high power LCUs.

2. The most toxic effects from resin core materials occur during the first $24 \mathrm{~h}$ of testing.

\section{Material and Methods \\ Cells}

The cells used for the experiments were L-929 mouse fibroblasts (L-929 An2 HÜKÜK 95030802; Ankara Şap Enstitüsü, Ankara, Turkiye). The cells were grown as monolayer cultures in T-25 flasks (Costar, Cambridge, MA, USA), subcultured three times a week at $37^{\circ} \mathrm{C}$ in an atmosphere of $5 \% \mathrm{CO}_{2}$ in air and $100 \%$ relative humidity and maintained at third passage. The culture medium was Dulbecco's modified Eagle medium (DMEM)/ Ham's F12 nutrient mixture (1:1; Sigma, St Louis, MO, USA) supplemented with $10 \%(\mathrm{v} / \mathrm{v})$ fetal bovine serum (FBS; Biochrom, Berlin, Germany) without antibiotics. Adherent cells at a logarithmic growth phase were controlled under an inverted tissue culture microscope (Olympus CK40, Japan) and detached with a mixture of $0.025 \%$ trypsin (Sigma) and $0.02 \%$ ethylenediaminetetraacetic acid (EDTA; Sigma), incubated for 2-5 min at $37^{\circ} \mathrm{C}$ and used for cell inoculation.

\section{Sample preparation}

Four resin core dental restorative materials $(2 \mathrm{~mm}$ in thickness and $6 \mathrm{~mm}$ in diameter) of shade A1 were used in this study ( $\mathrm{n}=84 /$ per group) (Table 1). All samples were prepared by the same operator. Fig. 1 shows the schematic illustration of sample preparation. The resin core materials were placed into sterile circular polytetrafluoroethylene moulds. Polyethylene films and a 1 $\mathrm{mm}$ glass slide were placed on top of the mould to exclude excessive resin core material and to eliminate air bubbles. Then the samples were irradiated from the top through polyethylene films under aseptic conditions at laminar flow (Holten, Class II, Denmark) using soft-up and high-power modes of QTH LCU (QTH, Blue Swan Digital, 03-185, Dentanet) $\left(1000 \mathrm{mw} / \mathrm{cm}^{2}\right)$, standard and exponential modes of LED LCU (LED, Elipar Freelight 2, 939820014022, 3M Espe) $\left(1200 \mathrm{mw} / \mathrm{cm}^{2}\right)$ and normal and ramp-curing modes of PAC LCU (PAC, PlasmaStar, SP-2000, P0500206, Monitex) $\left(2250 \pm 50 \mathrm{mw} / \mathrm{cm}^{2}\right)$. While high-intensity mode (provides full light intensity for the entire exposure period) corresponds to high power mode of QTH, standard mode of LED and normal mode of PAC; slow-up mode (curing cycle boost automatically from soft- start to high output) corresponds to soft-up mode of QTH, exponential mode of LED and ramp-curing mode of PAC.

The freshly prepared tested samples were placed immediately at the bottom of six well-plates (Costar, Cambridges, MA, USA). The samples were placed in 
Table 1. Test materials and their composition according to manufacturers.

\begin{tabular}{|c|c|c|c|c|}
\hline Trade Name & Code & Composition & Lot number & Manufacturer \\
\hline Rebilda DC & $\mathbf{A}$ & $\begin{array}{l}\text { Bis-GMA }{ }^{\text {a }} \text {, diurethane dimethacrylate, } \\
\text { BHT }^{\mathrm{b}} \text {, benzoyl peroxide }\end{array}$ & 700114 & $\begin{array}{l}\text { VOCO GmbH, Cuxhaven, } \\
\text { Germany }\end{array}$ \\
\hline $\begin{array}{l}\text { Clearfil DC Core } \\
\text { Automix }\end{array}$ & B & $\begin{array}{l}\text { Base: TEGDMA }{ }^{\mathrm{c}} \text {, methacrylate } \\
\text { monomers, silanized glass fillers, silica } \\
\text { microfillers, photo/chemical initiator } \\
\text { Catalyst: Bis-GMA, TEGDMA }{ }^{\mathrm{c}} \text {, } \\
\text { silanated glass filler, silica microfillers, } \\
\text { photo/chemical initiator }\end{array}$ & 00029A & $\begin{array}{l}\text { Kuraray Medical Inc., } \\
\text { Okayama, Japan }\end{array}$ \\
\hline BIS-CORE & $\mathbf{C}$ & $\begin{array}{l}\text { Base: BisGMA, glass filler, UDMA }{ }^{\mathrm{d}} \text {, } \\
\text { fused silica Catalyst: Bis-GMA }{ }^{\mathrm{a}} \text {, } \\
\text { benzoyl peroxide }\end{array}$ & 0700004102 & $\begin{array}{l}\text { Bisco Inc., Schaumburg, } \\
\text { U.S.A. }\end{array}$ \\
\hline Build-It FR & D & $\begin{array}{l}\text { BisGMA }^{\mathrm{a}}, \mathrm{UDMA}^{\mathrm{d}}, \mathrm{HDDMA}^{\mathrm{e}}, \text { Silane } \\
\text { treated barium boro-alumino silicate } \\
\text { glass, Silane treated chopped glass fibers, } \\
\text { Pigments with initiators, stabilizers, UV } \\
\text { absorbers }\end{array}$ & 143239 & $\begin{array}{l}\text { Pentron Clinical } \\
\text { Technologies, LLC, } \\
\text { Wallingford, U.S.A. }\end{array}$ \\
\hline
\end{tabular}

${ }^{a}$ Bis-GMA, Bis-phenol A diglycidylmethacrylate; ${ }^{\mathrm{b} B H T}$, Butylated hydroxy toluene; 'TEGDMA, Triethyleneglycol dimethacrylate; ${ }^{\mathrm{d} U D-}$ MA, Urethane dimetacrylate; ${ }^{\circ} \mathrm{HDDMA}$, Hexanediol dimethacrylate.

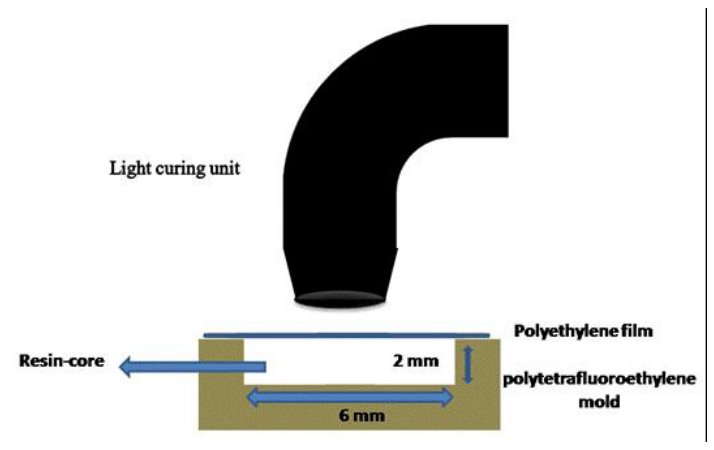

Fig. 1. Schematic illustration of sample preparation.

DMEM/F12 with $10 \%$ FBS and incubated at $37{ }^{\circ} \mathrm{C}$ in an atmosphere of $5 \% \mathrm{CO}_{2}$ in air without agitation for $24 \mathrm{~h}$ and $72 \mathrm{~h}$. After the incubation, the extracts were filtered through $0.22 \mu \mathrm{m}$ cellulose acetate filters (Millipore, Sigma, St. Louis, MO, USA).

Cytotoxicity testing (MTT assay)

The L-929 cell suspension with DMEM/F12 with $10 \%$ FBS and $1 \%$ antibiotic was prepared at a concentration of $3 \times 10^{4}$ cells mL- ${ }^{-1}$ and inoculated onto 96-well cluster cell culture plates $(100 \mu \mathrm{L}$ per well). The multiwell plates were incubated at $37^{\circ} \mathrm{C}, 5 \% \mathrm{CO}_{2}$ in air for $24 \mathrm{~h}$. After $24 \mathrm{~h}$, the culture medium was removed from the wells and equal volumes $(100 \mu \mathrm{L})$ of the extracts were added into each well. In control wells, $100 \mu \mathrm{L}$ DMEM/
F12 with 10\% FBS and 1\% antibiotic was added. After the 24 and $72 \mathrm{~h}$ incubation period test extracts were removed. Following removal of the test extracts, $100 \mu \mathrm{L}$ per well DMEM/F12 with $10 \%$ FBS and $1 \%$ antibiotic and $12 \mu \mathrm{L}$ MTT (tetrazolium salt 3-[4,5-dimethylthiazol-2-yl]-2,5- diphenyltetrazolium bromide) were added to each well and incubated in a dark environment for $4 \mathrm{~h}$ at $37^{\circ} \mathrm{C}$. Then, 96 wells were checked for formazan crystals with inverted tissue culture microscope. MTT was aspirated and $100 \mu \mathrm{L}$ per well of isopropanol (Merck, Darmstadt, Germany) was added to each well. Subsequently, the absorbance at $570 \mathrm{~nm}$ was measured using a UV-visible spectrophotometer (LPB Pharmacia, Bromma, Sweden). Then the viable cells were counted under a light microscope and calculated as a percentage of the controls. Each cytotoxicity assay was evaluated three times for each experimental group.

Statistical analysis

Multiple analysis of variance (MANOVA) was employed to ascertain the effect of the different factors: resin core material (Rebilda, Build-It FR, Clearfil DC Core and Bis-core), LCU (QTH, LED and PAC), curing mode (high-intensity and slow-up modes) and experimental time ( $24 \mathrm{~h}$ and $72 \mathrm{~h}$ ) on the dependent variable cytotoxicity. Interactions were included in the analysis. One-way ANOVA and Tukey's post-hoc tests or independent $t$ tests were performed for multiple comparisons $(\alpha=0.05)$ (SPSS 11.5, SPSS Inc., Chicago, IL, USA).

\section{Results}

The cytotoxic effects of the resin core materials, the LCUs, curing modes, and experimental times on the fibroblast cells' survival rates were evaluated by multiple 
analyses of variance. (Fig. 2) demonstrates the distribution of cell survival rates $(\%)$ of resin-core materials according to the LCUs. Additionally, the distribution of cell survival rates (\%) on light curing modes in each resin-core material is shown in (Fig. 3).

According to the statistical analysis, there were significant differences among the CSR \% of the tested materials $(\mathrm{F}=730.477, \mathrm{p}<0.001)$. The level of the tested materials' cytotoxicity can be rank based on the survival rates and ranking of those cytotoxicities (CSR \%) indicated by $\mathrm{C}>\mathrm{A} \approx \mathrm{D}>\mathrm{B}$. Statistically significant ranking for CSR \% of LCUs was obtained as follows: QTH $\approx$ LED $>$ PAC $(F=436.613, p<0.001)$. At the same time, statistically significant differences were found between curing modes of LCUs $(\mathrm{F}=402.878, \mathrm{p}<0.001)$. According to these results, mean CSR \% values of the tested materials acquired with high power, standard and normal modes were significantly higher than those obtained with softup, exponential and ramp-curing modes. Furthermore, a significant difference was observed in mean CSR \% values of the tested materials at different experimental times $(24 \mathrm{~h}$ and $72 \mathrm{~h})(\mathrm{F}=34.245, \mathrm{p}<0.001)$. The mean CSR \% results of the materials obtained at $24 \mathrm{~h}$ were higher than their CSR \% results obtained at $72 \mathrm{~h}$.

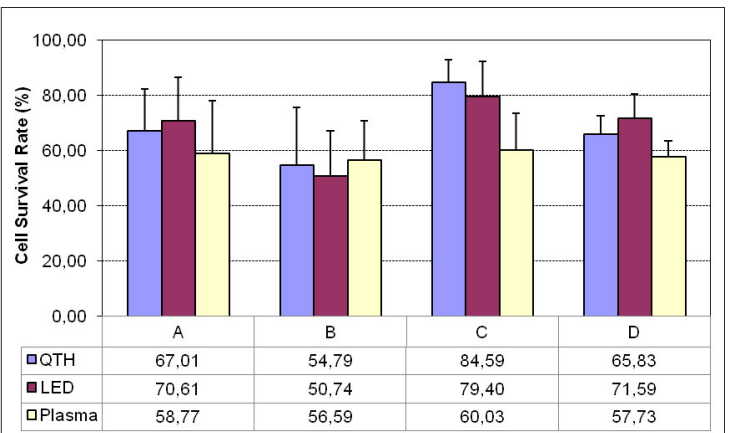

Fig. 2. The distribution of cell survival rates (\%) on LCUs. Cell survival rates were expressed as a percentage of controls (cultures without samples).

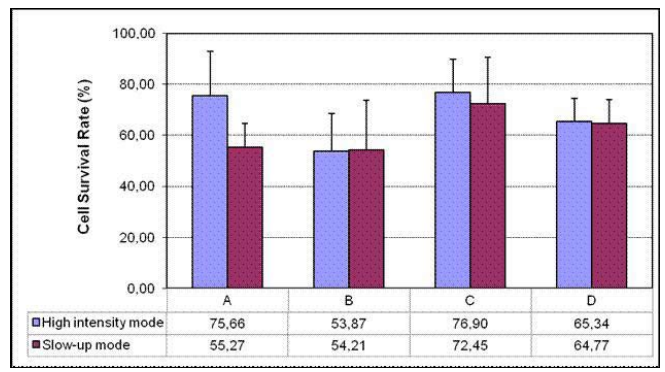

Fig. 3. The distribution of cell survival rates (\%) in each resin core material. Cell survival rates were expressed as a percentage of controls (cultures without samples).
The comparisons of cell survival rates among LCUs in each resin core material are presented in (Table 2). The interactions among the tested materials, LCUs, curing modes and experimental times demonstrated that material C cured with high-power mode of QTH at $24 \mathrm{~h}$ showed the highest CSR \% value (95.61\%), while material B cured with ramp-curing mode of PAC at $24 \mathrm{~h}$ showed the lowest CSR \% value (33.31\%).

\section{Discussion}

In the present study, it was hypothesized that the cytotoxic effects of cell culture at different experimental times would show dependence on the type of resin core materials cured with different curing modes of high power LCUs. According to the results, there were significant interactions among the tested materials, the LCUs, curing modes and the experimental times $(\mathrm{p}<$ 0.001). Thus, the first null hypothesis was accepted.

Both resin content and percentage of monomer conversion of dental materials were considered as potential causes of cytotoxicity (8). The filler/resin ratio is important, since penetration of light into the composite is more difficult when the filler proportion is higher (5). Additionally, increasing filler/resin ratio progressively decreases conversion (9). If a resin composite shows a low degree of monomer conversion toxic substances may leach into the environment (10). Moreover, a previous study by Caughman et al. (8) evaluated the correlation between cytotoxicity, filler loading and curing time of dental composites and concluded that the percentage of monomer conversion increased, when the cellular toxicity decreased. The amounts of fillers used in the present study were $65 \%, 68.2 \%, 70.2 \%$ and $74 \%$ by mass for $C$, $\mathrm{A}, \mathrm{D}$ and $\mathrm{B}$, respectively and the statistical ranking for $\mathrm{CSR} \%$ of the resin core materials were as follows: $\mathrm{C}>\mathrm{A}$ $\approx \mathrm{D}>\mathrm{B}$. These results were consistent with the previous studies as the filler content increases, the CSR $\%$ of the resin core materials increases.

Among the resin core materials used in this study, material $\mathrm{B}$ is a compound of Bis-phenol A diglycidylmethacrylate (Bis-GMA) and triethyleneglycol dimethacrylate (TEGDMA). The lowest CSR\% of material B might be attributed to this agent, as in previous studies, TEGDMA was found to cause apoptosis (11), reduce the glutathione transferase P1 activity of human gingival fibroblasts and depletion of intracellular glutathione, as a major natural reducing agent (12). While TEGDMA was reported as mutagenic in a mammalian cell gene mutation assay, no mutagenic effects were detected with Bis-GMA and UDMA in gene mutation assays (13).

The trend toward decreasing cytotoxicity of resin-based materials by time related with the decline in mass release, is confirmed in earlier investigations $(14,15)$. The high initial effect could be due to the fact that the leakage of substances from the materials occurs mainly dur- 
Table 2. The comparison of cell survival rates (CSR \%) of tested materials among LCUs and their modes at experimental times.

\begin{tabular}{|c|c|c|c|c|c|c|c|c|}
\hline \multirow[b]{2}{*}{$\begin{array}{c}\text { Tested } \\
\text { Materials }\end{array}$} & \multirow[b]{2}{*}{$\begin{array}{l}\text { Experimental } \\
\text { Time }\end{array}$} & \multirow[b]{2}{*}{$\begin{array}{l}\text { Modes of the } \\
\text { LCUs' }\end{array}$} & \multirow[b]{2}{*}{ LCUs } & \multirow[b]{2}{*}{ CSR \% } & \multicolumn{2}{|c|}{ Mean square } & \multirow[b]{2}{*}{$\mathbf{F}$} & \multirow[b]{2}{*}{$P$} \\
\hline & & & & & $\begin{array}{l}\text { Between } \\
\text { Groups }\end{array}$ & $\begin{array}{c}\text { Within } \\
\text { Groups }\end{array}$ & & \\
\hline \multirow{12}{*}{ A } & \multirow{6}{*}{$24 \mathrm{~h}$} & Soft-up & QTH & 50.25 & \multirow{3}{*}{0.484} & \multirow{3}{*}{3.846} & \multirow{3}{*}{0.126} & \multirow{3}{*}{0.884} \\
\hline & & Exponential & LED & 51.02 & & & & \\
\hline & & Ramp-curing & PAC & 50.86 & & & & \\
\hline & & High-power & QTH & 88.40 & \multirow{3}{*}{12.606} & \multirow{3}{*}{8.130} & \multirow{3}{*}{1.551} & \multirow{3}{*}{0.287} \\
\hline & & Standard & LED & 92.49 & & & & \\
\hline & & Normal & PAC & 90.55 & & & & \\
\hline & \multirow{6}{*}{$72 \mathrm{~h}$} & Soft-up & QTH & 58.62 & \multirow{3}{*}{527.240} & & & \\
\hline & & Exponential & LED & 73.64 & & 4.392 & 120.047 & $<0.001^{*}$ \\
\hline & & Ramp-curing & PAC & 47.20 & & & & \\
\hline & & High-power & QTH & 70.78 & & & & \\
\hline & & Standard & LED & 65.30 & 488.489 & 6.249 & 78.174 & $<0.001^{*}$ \\
\hline & & Normal & PAC & 46.45 & & & & \\
\hline & & Soft-up & QTH & 36.47 & & & & \\
\hline & & Exponential & LED & 37.85 & 16.266 & 0.396 & 41.066 & $<0.001^{*}$ \\
\hline & & Ramp-curing & PAC & 33.31 & & & & \\
\hline & $24 \mathrm{~h}$ & High-power & QTH & 33.88 & & & & \\
\hline & & Standard & LED & 36.56 & 919.106 & 0.905 & 1016.010 & $<0.001 *$ \\
\hline & & Normal & PAC & 65.45 & & & & \\
\hline B & & Soft-up & QTH & 78.43 & & & & \\
\hline & & Exponential & LED & 75.34 & 177.225 & 3.759 & 47.144 & $<0.001^{*}$ \\
\hline & & Ramp-curing & PAC & 63.84 & & & & \\
\hline & $72 \mathrm{~h}$ & High-power & QTH & 70.36 & & & & \\
\hline & & Standard & LED & 53.20 & 449.508 & 13.326 & 101.194 & $<0.001 *$ \\
\hline & & Normal & PAC & 63.77 & & & & \\
\hline & & Soft-up & QTH & 87.94 & & & & \\
\hline & & Exponential & LED & 94.04 & 1392.320 & 4.196 & 331.807 & $<0.001 *$ \\
\hline & & Ramp-curing & PAC & 54.05 & & & & \\
\hline & $24 \mathrm{~h}$ & High-power & QTH & 95.61 & & & & \\
\hline & & Standard & LED & 86.38 & 180.794 & 3.926 & 46.046 & $<0.001 *$ \\
\hline$C$ & & Normal & PAC & 80.18 & & & & \\
\hline$C$ & & Soft-up & QTH & 78.50 & & & & \\
\hline & & Exponential & LED & 75.20 & 1025.537 & 2.719 & 377.228 & $<0.001 *$ \\
\hline & & Ramp-curing & PAC & 44.95 & & & & \\
\hline & $72 \mathrm{~h}$ & High-power & QTH & 76.29 & & & & \\
\hline & & Standard & LED & 61.97 & 220.904 & 4.050 & 54.547 & $<0.001^{*}$ \\
\hline & & Normal & PAC & 60.94 & & & & \\
\hline & & Soft-up & QTH & 75.73 & & & & \\
\hline & & Exponential & LED & 69.85 & 413.794 & 2.943 & 140.626 & $<0.001^{*}$ \\
\hline & & Ramp-curing & PAC & 53.10 & & & & \\
\hline & $24 \mathrm{~h}$ & High-power & QTH & 64.12 & & & & \\
\hline & & Standard & LED & 82.60 & 301.472 & 4.439 & 67.909 & $<0.001^{*}$ \\
\hline & & Normal & PAC & 66.62 & & & & \\
\hline D & & Soft-up & QTH & 57.92 & & & & \\
\hline & & Exponential & LED & 74.11 & 262.089 & 3.085 & 84.963 & $<0.001 *$ \\
\hline & & Ramp-curing & PAC & 57.92 & & & & \\
\hline & $72 \mathrm{~h}$ & High-power & QTH & 65.56 & & & & \\
\hline & & Standard & LED & 59.82 & 112.663 & 0.924 & 121.928 & $<0.001^{*}$ \\
\hline & & Normal & PAC & 53.31 & & & & \\
\hline
\end{tabular}

*indicates significant differences at $\mathrm{p}<0.05$ (LCUs: Light curing units. CSR: Cell survival rate). 
ing the first day. A previous study by Franz et al. (14) evaluated the cytotoxicity of packable and nonpackable composite materials for 1, 2, 7 days or 6 weeks and found that the cytotoxicity of all substances diminished with increasing preincubation times. This finding was in accordance with the present study showing that CSR $\%$ of the materials obtained at $24 \mathrm{~h}$ was higher than their CSR \% results obtained at $72 \mathrm{~h}$, leading to the acceptance of the second null hypothesis.

The choice of the curing light and modes are also the important parameters affecting the release of toxic substances from resin-based materials $(16,17)$. If resin-core systems are not cured thoroughly and do not reach a sufficient degree of monomer conversion, they can leach toxic and carcinogenic substances into the body of the patient (10). In the current study, the cytotoxic effects of various resin-based core materials were similar when cured with QTH and LED. The finding of the current study was in accordance with the finding of Uhl et al. (10) whom found no considerable difference in the temperature increase or the number of living cells within a pulp chamber model between halogen LCU and LED LCU.

A previous study reported that a given energy density can be delivered with different combinations of power density and exposure duration and they concluded that a reciprocal relationship exists between power density and exposure duration (16). In the present study, Elipar Freelight 2, a high-intensity LED LCU, has exposure time options as follows: $5,10,15$ and $20 \mathrm{sec}$ according to the manufacturer's instructions. Because of the high light intensity $\left(1200 \mathrm{~mW} / \mathrm{cm}^{2}\right)$ of this LCU, these time periods corresponds to the time periods $(10,20$, 30 and $40 \mathrm{sec}$ ) of conventional light curing unit that has light intensity of $600-800 \mathrm{~mW} / \mathrm{cm}^{2}$ for halogen technology or $300-400 \mathrm{~mW} / \mathrm{cm}^{2}$ light intensity for LED. Thus, the normal exposure times for conventional units can be cut in half without compromising curing performance. Similarly, according to the manufacturer's instructions of PAC LCU that has been used in this study, this LCU can produce four times as much of light intensity as the conventional LCU. Thereby, the curing time could be shortened to as much as $1 / 4$ of the curing time of the conventional halogen lamp. Therefore, in the present study, resin core materials were cured with high intensity QTH (high power and soft-up modes) for $20 \mathrm{sec}$, with LED (standard and exponential modes) for $20 \mathrm{sec}$, with normal mode of PAC $10 \mathrm{sec}$ and with ramp-curing mode of PAC for $6 \mathrm{sec}$. The mean CSR\% values of high intensity modes were found to be significantly higher than slow-up modes. This could be attributed to the uncured monomers and the differences between the polymer networks of resin-core materials formed after curing with high-intensity and slow-up modes. Furthermore, these observations might suggest that slow-up modes are less efficient in monomer conversion than high intensity modes. When the conversion value is lower than optimal, monomer leaching from resin based material will damage the cells (17). A previous study by Knezevic et al. (18) investigated the curing mode intensities on cell culture cytotoxicity/genotoxicity and indicated the higher DNA damage measured for cultures cured by low intensity mode when compared to the other modes (high intensity and soft start). In another study by Knezevic et al. (19), they compared the cytotoxicity of composite materials cured with different modes (high intensity, soft start and low intensity modes) of LED LCUs and concluded that longer curing time with lower intensity results in less cytotoxicity than shorter curing exposure using higher intensity of light.

All LCUs produce heat during polymerization at varying levels. Furthermore, resin composites generate some heat while they polymerize. Even though PAC LCUs polymerize faster than other LCUs, they cause a higher risk of pulpal damage due to their increased heat generation compared to other LCUs (20). In previous studies, PAC LCU was shown as the most potent elevator of temperature $(20,21)$. Nevertheless, Uhl et al. (10) investigated the effect of heat from light curing units and dental composite curing on cells in vitro and indicated not only that the temperature may have an effect on the living cells, but also that cells may be negatively affected by the uncured composite or light of the LCUs. In the present study, the relation between the light curing unit and the composition of the material seems to be evident for all the resin-core materials except material $\mathrm{B}$, where curing quality possibly reduces the amount of free toxic substances. The reduction in cell viability of material A, C, D was $41 \%, 40 \%, 42 \%$ less after use of PAC as compared with other LCUs, respectively (Fig. 2). It can be assumed that a high energy density of PAC LCU $\left(2250 \pm 50 \mathrm{mw} / \mathrm{cm}^{2}\right)$ produced a more cytotoxic effect than QTH and LED LCUs. In accordance with the present study, Wataha et al. (22) evaluated the biological effects of three different LCUs (QTH, PAC and laser) on the cellular function of fibroblasts in vitro. They found that while PAC suppressed the succinic dehydrogenase activity of mitochondria (cell function), QTH and laser did not suppress the activity. Therefore, a long curing time more than recommended can cause biological damage on the oral tissue.

In vitro standardization of cytotoxicity testing that can simulate in vivo situation would enhance biocompatibility of new restorative biomaterials, and determine the curing efficiency of innovative LCUs. Further research on the elution time and release of components from resin-based materials cured with different curing modes and methods would be helpful to better understand the biological risks of these restorative materials and LCUs. 


\section{Conclusions}

Within the limitations of this in-vitro study, the following conclusions could be drawn:

1. The resin-core materials and different LCUs with various curing modes should be harmonized to one another for achieving maximal biocompatibility.

2. QTH and LED with high-intensity modes might be beneficial for curing of resin-core systems with regard to the release of toxic substances.

\section{References}

1. Wataha JC, Lockwood PE, Bouillaguet S, Noda M. In vitro biological response to core and flowable dental restorative materials. Dent Mater. 2003;19:25-31.

2. Ariyoshi M, Nikaido T, Foxton RM, Tagami J. Microtensile bond strengths of composite cores to pulpal floor dentin with resin coating. Dent Mater J. 2008;27:400-7.

3. Ceballos L, Fuentes MV, Tafalla H, Martínez A, Flores J, Rodríguez J. Curing effectiveness of resin composites at different exposure times using LED and halogen units. Med Oral Patol Oral Cir Bucal. 2009;14:E51-6.

4. Yap AU, Wong NY, Siow KS. Composite cure and shrinkage associated with high intensity curing light. Oper Dent. 2003;28:357-64.

5. Soares LE, Liporoni PC, Martin AA. The effect of soft-start polymerization by second generation LEDs on the degree of conversion of resin composite. Oper Dent. 2007;32:160-5.

6. Hervás-García A, Martínez-Lozano MA, Cabanes-Vila J, Barjau-Escribano A, Fos-Galve P. Composite resins. A review of the materials and clinical indications. Med Oral Patol Oral Cir Bucal. 2006;11:E215-20.

7. Goldberg M. In vitro and in vivo studies on the toxicity of dental resin components: a review. Clin Oral Investig. 2008;12:1-8.

8. Caughman WF, Caughman GB, Shiflett RA, Rueggeberg F, Schuster GS. Correlation of cytotoxicity, filler loading and curing time of dental composites. Biomaterials. 1991;12:737-40.

9. Halvorson RH, Erickson RL, Davidson CL. The effect of filler and silane content on conversion of resin-based composite. Dent Mater. 2003;19:327-33.

10. Uhl A, Völpel A, Sigusch BW. Influence of heat from light curing units and dental composite polymerization on cells in vitro. J Dent. 2006;34:298-306

11. Samuelsen JT, Dahl JE, Karlsson S, Morisbak E, Becher R. Apoptosis induced by the monomers HEMA and TEGDMA involves formation of ROS and differential activation of the MAP-kinases p38, JNK and ERK. Dent Mater. 2007;23:34-9.

12. Bakopoulou A, Tsiftsoglou A, Galaktidou G, Markala D, Triviai I, Garefis P. Patterns of cell death and cell cycle profiles of cultured WEHI 13 var fibroblasts exposed to eluates of composite resins used for direct and indirect restorations. Eur J Oral Sci. 2007;115:397407.

13. Schweikl H, Schmalz G, Spruss T. The induction of micronuclei in vitro by unpolymerized resin monomers. J Dent Res. 2001;80:161520.

14. Franz A, Konradsson K, König F, Van Dijken JW, Schedle A. Cytotoxicity of a calcium aluminate cement in comparison with other dental cements and resin-based materials. Acta Odontol Scand. 2006;64:1-8.

15. Schedle A, Franz A, Rausch-Fan X, Spittler A, Lucas T, Samorapoompichit $\mathrm{P}$, et al. Cytotoxic effects of dental composites, adhesive substances, compomers and cements. Dent Mater. 1998;14:42940.

16. Halvorson RH, Erickson RL, Davidson CL. Energy dependent polymerization of resin-based composite. Dent Mater. 2002;18:463-9.

17. Tseng WY, Huang CH, Chen RS, Lee MS, Chen YJ, Rueggeberg FA, et al. Monomer conversion and cytotoxicity of dental composites irradiated with different modes of photoactivated curing. J Biomed
Mater Res B Appl Biomater. 2007;83:85-90.

18. Knezevic A, Zeljezic D, Kopjar N, Tarle Z. Cytotoxicity of composite materials polymerized with LED curing units. Oper Dent. 2008;33:23-30.

19. Knezevic A, Zeljezic D, Kopjar N, Tarle Z. Influence of curing mode intensities on cell culture cytotoxicity/genotoxicity. Am J Dent. 2009;22:43-8.

20. Antonson SA, Antonson DE, Hardigan PC. Should my new curing light be an LED? Oper Dent. 2008;33:400-7.

21. Wataha JC, Lewis JB, Lockwood PE, Noda M, Messer RL, Hsu S. Response of THP-1 monocytes to blue light from dental curing lights. J Oral Rehabil. 2008;35:105-10.

22. Wataha JC, Lockwood PE, Lewis JB, Rueggeberg FA, Messer RL. Biological effects of blue light from dental curing units. Dent Mater. 2004;20:150-7.

This study was presented at the Pan European Federation of the International Association for Dental Research (IADR) in London, UK on September, 10-12, 2008. 